\title{
Effect of Potting Media and Watering Frequency on Growth Rate of Seedling of Korarima (Aframomum Cororima (Braun) P.C.M. Jansen) Under Nursery
}

\author{
Jafer Dawid* \\ Jimma Agricultural Research Center, Jimma Ethiopia.
}

*Corresponding Authors: Jafer Dawid, Jimma Agricultural Research Center, Jimma Ethiopia.

\begin{abstract}
Korarima (Aframomum corrorima) is native crop to Ethiopia, tropical herbaceous, perennial and aromatic spice and medicinal crop widely used in traditional dishes, and sold at higher prices. Relative growth rate $(R G R)$ is one of the most widely used measurements of plant performance. RGR to be determined by their higher leaf area ratio, which in turn is accounted for by their higher net assimilates rate compared to others and Leaf Area Ratio is a better determinant of RGR as seedlings with higher specific leaf area and Leaf Area Ratio under water stress and nutrient had very poor RGR values. Lack of improved variety and Poor agronomic practices limit the Production much lower. Thus, the current study was conducted to determining growth rate on Seedling of Korarima under media and watering frequency at Jimma Research Center, southwest Ethiopia. Experiment has two factors. Soil media seven levels and Watering frequency days four levels \& using split plot design with three replications.. The results of the experiment ANOVA indicated that there were interaction effect of between the factors were highly significant $(P<0.1)$ in respect of $R G R$ parameters. Korarima seeds sown in mixed forest and top soil and also top soil and compost soil media combination ratio with watering frequency every one and two days gave significant growth parameters, dry weight and relative growth rate .. In general, all treatments showed Highly significant $(p<0.01)$ variation in terms of leaf area, leaf number, total dry weight, relative growth rate .
\end{abstract}

Keywords: Korarima (Aframomum corrorima), soil media, Watering frequency, seedling growth, Relative growth rate

\section{INTRODUCTION}

Aframomum corrorima is a species in the ginger family, Zingiberaceae. The spice, known as korarima, Ethiopian cardamom, or false cardamom, is obtained from the plant's seeds (usually dried), and is extensively used in Ethiopian cuisine (Braun, 2011). It is an ingredient in berbere, mitmita, awaze, and other spice mixtures, and is also used to flavor coffee (Bernard R. and François V., 2003). The plant is native to Tanzania, western Ethiopia (in the vicinity of Lake Tana and Gelemso), south western Sudan, western Uganda (Braun, 2011) As indigenous spice, Aframomum corrorima grows in various parts of the country; Kaffa, Jimma, East and West Wollega, Sidamo, Bale, South and North Omo, Illubabour, East and West Gojam, Gamugofa, etc. (Jansen, 1981; Edossa, 1998; Simegn et al., 2016). It is a shade loving plant that grows in almost the same habitats as wild Arabica coffee in high rain forests areas of the country (Jansen, 2002). Growth medium has been found to be the most critical factor determining seedling quality in the nursery (Baiyeri and Mbah, 2006), acting as a reservoir for nutrients, moisture and oxygen supply to the growing plant (Baiyeri, 2005).Seedlings grown on substrates containing organic component with both mineral fractions had thicker and longer stem and higher growth rate, which indicates better rate of photosynthesis. Also, the increase in leaf area for increase in dry matter was higher which produces better seedling in these growth media (H. Mirseyed et al..2017). According to (H. Mirseyed et al..2017) water is an important factor in the growth, development and productivity of plants. reported that water stress due to drought is the most significant abiotic factor limiting plant relative growth rate and development.

The biomass of a plant about $95 \%$ are derived from the carbohydrates manufactured in the green parts by the process of photosynthesis and the remaining 5\% come from mineral elements absorbed by the roots and the capacity of the plant to produce carbohydrate depends mainly on the total green (mainly 
leaf) area engaged in photosynthesis and the net photosynthetic rate per unit green surface area, and dry matter production in any crop depends upon leaf area index, structure of the canopy photosynthetic rate per unit of leaf area and strength of the metabolic sinks in attracting assimilates (Taye Kufa, 2012). Species adapted to high-resource environments have high potential rates of resource capture and growth relative, high-light early-succession sites where a high RGR and associated traits, such as high SLA, SRL, LAR, RLR and NAR (plus high photosynthetic and nutrient uptake rates (Cornelissen et al. 1998).

Relative growth rate (RGR) is one of the most widely used measurements of plant performance (Poorter \& Lambers 1991). According (Gbadamosi Alaba Emmanuel ,2014), there were some wide variations in Relative growth rate (RGR) of seedlings among treatments; this is often adduced to variations in SLA. Cornelissen et al.( 1998) stated that RGR of some species seems to be determined by their higher LAR, which in turn is accounted for by their higher net assimilates rate (SLA) compared to others and Leaf Area Ratio (NAR) is a better determinant of RGR as seedlings with higher SLA and LAR under water stress had very poor RGR values.

In Ethiopia, there is limited information about the soil media and water on relative growth rate of the crop spice. Therefore, the objective of this study was the effect of different nursery media compositions and watering frequency on relative growth rate of korarima seedlings.

\section{MATERIALS AND MethodS}

The experiment was conducted at a common nursery garden of the Jimma Research Center, southwest Ethiopia (latitude of 70, 46" N, and longitude of 300, 50"E, 1750 m.a.s.l). The average maximum and minimum air temperatures are $26.3^{\circ} \mathrm{C}$ and $11.6^{\circ} \mathrm{C}$, respectively. The area receives adequate amount of rain- fall with an average rainfall of $1530 \mathrm{~mm}$ per annum, with $66 \%$ of average relative humidity.

\subsection{Experimental Treatments and Design}

Fully ripened bold red capsules of local land race of korarima (Jimma) were harvested and fresh capsules were split open and seeds were extracted from the capsules. The seven planting growth soil media consisting of forest soil, top soil and compost prepared from decomposed grass, coffee pulp, top soil and cow dung at the respective proportion ( $\mathrm{v} / \mathrm{v})$ and firmly filled in to black polythene bag of $16 \mathrm{~cm}$ wide and $22 \mathrm{~cm}$ length. A single experimental unit (plot) consisted of 12 pots were arranged in rectangle fashion $(3 \times 4)$ on nursery bed. Then, uniform and healthy seeds were selected and the prepared korarima seeds were sown in each pot. The recommended post-sowing nursery operations were applied (IAR,(1996) and the seedlings were uniformly managed under partial shade conditions and irrigated based on the treatments. When it rains, experimental units (plots) were covered by plastic sheet. Four months after sowing the central four korarima seedlings were used to record destructive growth parameters for each treatment. These include dry weight of leaves, stem, and root. The roots were immersed and washed in clean water to remove adhering soil. Subsequently, each plant part was separately oven-dried at $70^{\circ} \mathrm{C}$ until a constant weight obtained and weighed using a sensitive balance. Finally, total dry matter production and allocation patterns were determined in seedlings of korarima. A split plot design of three replication was employed with seven soil media(forest soil alone, top soil alone, and mixture of forest and top soil in 1:1 ratio, forest soil and compost in 1:1 ratio, top soil and compost in 1:1, forest soil, top soil and compost in 1:1:1 ratio, and top soil and compost in 3:1 ratio) and four watering frequency treatments (every day, every two days, every three days and every four days) were assigned as main plot and subplots, respectively.

Leaf area (fully-grown green leaves) was calculated by measuring the leaf length ( $\mathrm{cm}$ )and maximum leaf width $(\mathrm{cm})$ using ruler to get the estimated leaf area; the actual leaf area constructed by tracing the leaf on square paper then calculate the area and then to get $\mathrm{k}$ factor divide the actual area of the leaf over estimate area of the same leaf this was to get $k$ factor(correction factor) Yakob et al. (1995) for the procedure as follows:

Leaf area $\left(\mathrm{cm}^{2}\right)$ leaf length from petiole to the tip and leaf width at broadest part was measured.

$\mathbf{E}=\mathrm{K} \times \mathrm{L} \times \mathrm{B}$

Where: $\mathrm{E}=$ estimated leaf area, $\mathrm{K}=$ factor, $\mathrm{L}=$ leaf length $(\mathrm{cm}), \mathrm{B}=$ maximum leaf breadth $(\mathrm{cm})$ 
Likewise, destructive plant growth parameters such as fresh and dry weight of leaves, stems, and roots; total dry matter, were recorded. The largest root length, root length between the collar region and the tip of the root were measured using rulers and the mean value was recorded in $\mathrm{cm}$. by uprooting four randomly selected seedlings next to the border from each plot. Each seedling sampled for measurement of non-destructive parameters was brought to the laboratory for destructive parameters. Seedlings were cut with a scissor at collar point to separate the shoot from the root. The shoot, then, was separated in to leaves and stems and fresh weight of each was weighed using sensitive balance. The polythene bag containing the roots of the seedlings was then, immersed in a bucket filled with water and roots were carefully separated from the soil still being in water. The roots were subsequently washed with clean water; surface dried with water adsorbent cloth and fresh weight was measured following the same procedures described for the shoot.. Finally, the entire seedling parts were oven dried at $70^{\circ} \mathrm{C}$ until a constant weight as described by Adjet-Twum and Solomon (1982) and dry matter yield was determined using sensitive balance.

The raw data were used to calculate the following growth parameters:

Growth rate of seedlings was determined by measuring initial and final total dry matter yield of randomly selected plants from each plot using the formula described by (Hunt, 1990) as follows:

$$
\begin{aligned}
& \text { RGR }=\text { NAR } \times \text { SLA } \times \text { LWF or } \quad \text { RGR }=\text { NAR } \times L A R, ~ L A R=L W R \times S L A
\end{aligned}
$$

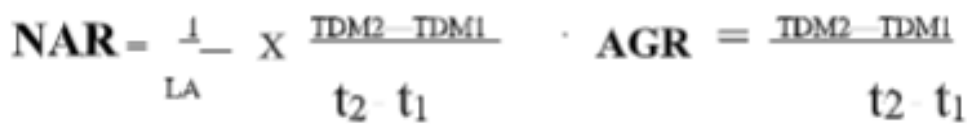

$$
\begin{aligned}
& \mathbf{L W R}=\frac{L W}{\mathrm{TDM}}, \quad \text { SLA }=\frac{L \Lambda}{L W}, \quad \text { LAR }=\frac{L \Lambda}{\mathrm{O} \text { or }}-\mathrm{LWR} \times \text { SLA) }
\end{aligned}
$$

\section{Where:}

$$
\begin{aligned}
& \mathrm{W}=\text { Total dry weight per plant, } \quad \mathrm{T} \mathrm{LA}=\text { Total Leaf Area per plant } \\
& \text { LA = Leaf Area LW = Total Leaf Dry Weight per plant } \\
& \text { LWF }=\text { Leaf Weight Fraction } \quad \text { LWR }=\text { Leaf Weight Ratio } \\
& \text { LAR }=\text { Leaf Area Ratio } \quad \text { NAR }=\text { Net Assimilation Rate } \\
& \text { SLA }=\text { Specific Leaf Area } \quad \text { RGR }=\text { Relative Growth Rate }, \text { TDM }=\text { Dry plant biomass }
\end{aligned}
$$

TDM1 $=$ Total dry Matter of growth one in days or month, $\mathrm{t}=$ in days

$\mathrm{DM} 2=$ Total dry Matter of growth two in days or month

The product of SLA and LWF, defined as LA/W and known as leaf area ratio (LAR, total leaf area: total dry weight), NAR (net assimilation rate: rate of increase in plant mass per unit leaf area), specific leaf area (SLA, leaf area: leaf dry weight), LWF (leaf dry weight: plant dry weight).

\subsection{Data Analysis}

The collected data were processed and the statistical analysis was accomplished using SAS computer software Version 9.2 (SAS, 2008). The analysis of variance (ANOVA) was computed for each growth variable considered. Moreover, significant differences among the treatments were compared using Fisher's Least Significance Difference (LSD) at $<5 \%$ probability level.

\section{RESULTS AND DISCUSSION}

\subsection{Shoot height}

The interaction of soil media and watering frequency was highly significant $(\mathrm{P}<0.01)$ for Shoot height . The highest mean values of Shoot height $21.33 \mathrm{~cm}$ was recorded for seeds sown in top soil and compost mixture at 1:1 ratio and watering frequency every day $\left(\mathrm{M}_{5} \mathrm{WF}_{1}\right)$ or watering frequency every four days $\left(\mathrm{M}_{5} \mathrm{WF}_{4}\right)$ at four months of growth stages after sowing (Table 1). The lowest value recorded for shoot height at four months of growth stages after sowing were $13.25 \mathrm{~cm}$ and $12.58 \mathrm{~cm}$ 
for seeds sown in a blend of forest soil, top soil and compost in 1:1:1 ratio and watering frequency every four days $\left(\mathrm{M}_{6} \mathrm{WF}_{4}\right)$ and seeds sown in mixture of top soil and compost in 3:1 ratio and watering frequency every three days $\left(\mathrm{M}_{7} \mathrm{WF}_{3}\right)$, respectively .

The growth rate in terms of shoot height was, however, not consistent with the growth stages order. The highest mean values of shoot height 3.47was recorded for seeds sown top soil and watering frequency every day $\left(\mathrm{M}_{2} \mathrm{WF}_{1}\right)$ at two months of growth tage after sowing.where as seeds sown in top soil and compost mixture in 1:1 ratio and watering frequency every day $\left(\mathrm{M}_{5} \mathrm{WF}_{1}\right)$ and seeds sown in top soil and compost mixture in 1:1 ratios and watering frequency every four days $\left(\mathrm{M}_{5} \mathrm{WF}_{4}\right)$ exihibit the highest growth rate at four months of growth stages after sowing.From the result indicated in the table 12 after two months of growth stage enrich nutrient soil and watering holding capacity media needed as growth of seedling increase to escape from the stress to get tolerant and high number of transplanting seedling. This suggested that $\mathrm{M}_{5} \mathrm{WF} 4$ (seeds sown in top soil and compost mixture in 1:1 ratio and watering frequency every four days) was tolerant to in terms of shoot height. The shoot height increased due to the media has got frequently water. This result similar with work of Mohammed .(2004) the rate of vegetative growth of shoot height is enhanced by increases in available soil water content in the root zone, reduction in shoot height was observed due to less frequency of water for soil medium.

\subsection{Root length}

Root length significantly affected by interaction of soil media watering frequency. The highest mean values of root length $17.71 \mathrm{~cm}$ was exhibited for seeds sown in top soil and watering frequency every day $\left(\mathrm{M}_{2} \mathrm{WF}_{1}\right)$ at four months of growth stages of seedling after sowing. Similarly, higher values were recorded $16.81 \mathrm{~cm}$ for seeds sown in forest soil media and watering frequency every three days $\left(\mathrm{M}_{1} \mathrm{WF}_{3}\right), 17.17 \mathrm{~cm}$ seeds sown in a blend of forest soil, top soil and compost in 1:1:1 ratio and watering frequency every day $\left(\mathrm{M}_{6} \mathrm{WF}_{1}\right)$ and $16.61 \mathrm{~cm}$ seeds sown in top soil and compost mixture in 3:1 ratio and watering frequency every two days $\left(\mathrm{M}_{7} \mathrm{WF}_{2}\right)$ at four months of growth stages of seedling after sowing.The lowest value recorded for root length was $10.55 \mathrm{~cm}$, for seeds sown in top soil and compost mixture in 0.5:0.5 ratio and watering frequency every four days $\left(\mathrm{M}_{5} \mathrm{WF}_{4}\right)$ (Table 1). The responses of korarima seed to growth media types watering frequency could be associated with the variations in physical and chemical characteristics of the media mixes used in this experiment. In the present study, although the highest longest roots were recorded from the top soil medium, root development in terms of, root number and fresh and dry masses of roots were less in Top medium than the rest media. This may be associated with the differences in water holding capacity of the stated media types.

The observed variations hence indicate the intolerance of korarima seed to moisture stress and confirm their requirement for a growth medium possessing a relatively higher water holding capacity. The result of this study are consistent with the finding of Tisdale et al., (1993) the rate and direction of root growth are determined, principally, by soil water gradients; roots grow from areas of low water concentration to areas of high water concentration and they are unable to grow through zones of dry soil. Soil water level also has a pronounced effect on the uptake of plant nutrients by frequency water.

\subsection{Stem girth}

Highly significant $(\mathrm{P}<0.01)$ interaction differences were also noted in factors of soil media and watering frequency on girth $(\mathrm{cm})$ and Root No. The highest mean value of Girth diameter in $\mathrm{cm} 0.70$ $\mathrm{cm}$ for seeds sowing in mixture of top soil and compost in 3:1 ratio and watering frequency every two days $\left(\mathrm{M}_{7} \mathrm{WF}_{2}\right)$ at four months of growth stages after sowing (Table 1). While seeds sown in top soil and compost mixed at 3:1 ratio and watering frequency every three days $\left(\mathrm{M}_{7} \mathrm{WF}_{3}\right)$ showed the minimum values of girth $(0.45 \mathrm{~cm})$. Stem diameter increase is due to increasing of in available soil water content of the combination of the soil , conversely, reduction of stem girth due to decreasing water frequency and less uptake of nutrient. The adverse effect of moisture stress on leaf growth and leaf area has been observed in korarima seedling due to less frequent of water, this revealed that in addition to leaf enlargement, stem diameter and plant height also decreases with the development of the gap of water frequency . 
Effect of Potting Media and Watering Frequency on Growth Rate of Seedling of Korarima (Aframomum Cororima (Braun) P.C.M. Jansen) Under Nursery

\subsection{Root volume}

Two way interaction effects of soil media and watering frequency application resulted in highly significant $(\mathrm{P}<0.01)$ response of root volume $(\mathrm{ml})$; besides, the main effects of both soil media and watering frequency were significant $(\mathrm{p}>0.05)$ on root volume $(\mathrm{ml})$. The highest record for seeds sown in top soil media and watering frequency every two days $\left(\mathrm{M}_{2} \mathrm{WF}_{2}\right)(9.67 \mathrm{ml})$, seeds sowing in mixture of forest and top soil in 1:1 ratio and watering frequency every day $\left(\mathrm{M}_{3} \mathrm{WF}_{1}\right)(10.33 \mathrm{ml})$ and seeds sown in top soil and compost mixture at $1: 1$ ratio and watering frequency every day $\left(\mathrm{M}_{5} \mathrm{WF}_{1}\right)(10.00 \mathrm{ml})$. Similarly, seeds sown in top soil and compost mixture at 1:1 ratio and watering frequency every two days $\left(\mathrm{M}_{5} \mathrm{WF}_{2}\right)$ exhibited higher mean values $(9.33 \mathrm{ml})$ were recorded at four months seedling growth stage. While the lowest value $(2.33 \mathrm{ml})$ was observed for seeds sown in forest soil and compost mixture at 1:1 ratio and watering frequency every four days $\left(\mathrm{M}_{4} \mathrm{WF}_{4}\right)$ and seeds sown in a blend of forest soil, top soil and compost in 1:1:1 ratio and watering frequency every three days (Table 1). In general, highly significant differences in root development, root number, root volume, root length, as well as fresh and dry mass of roots were observed or raised not only on different media types also watering frequency considered in this study. From this study the lowest value observed due to less days of watering frequency factor than soil media factor This is consistent with the finding of Simon et al.(2011) application of water frequency every day or every two days increase height, survival rate and root volume of the seedling.In contrast, limited application of water had negative effection seedling height,root volume and number of leaves produced.

Table1. Interaction effect of soil media and watering frequency on shoot height, root length, girth and Root vol.

\begin{tabular}{|c|c|c|c|c|}
\hline Treatment & Shoot height $(\mathrm{cm})$ & $\begin{array}{l}\text { Root length } \\
\quad(\mathrm{cm})\end{array}$ & $\operatorname{Girth}(\mathbf{c m})$ & Root Vol.ml \\
\hline M1WF1 & $15.4^{\mathrm{fg}}$ & $13.59^{\mathrm{g}-\mathrm{i}}$ & $0.57^{\mathrm{fg}}$ & $6.33^{\mathrm{e}-\mathrm{h}}$ \\
\hline M1WF2 & $16.56^{\mathrm{e}}$ & $15.50^{\mathrm{c}-\mathrm{f}}$ & $0.57^{\mathrm{fg}}$ & $3.00^{1-n}$ \\
\hline M1WF3 & $18.33^{\mathrm{cd}}$ & $16.81^{\mathrm{ab}}$ & $0.64^{\mathrm{bcd}}$ & $2.67^{\mathrm{mn}}$ \\
\hline M1WF4 & $14.43^{\mathrm{h}}$ & $14.41^{\mathrm{f}-\mathrm{h}}$ & $0.61^{\mathrm{def}}$ & $5.33^{\mathrm{g}-\mathrm{j}}$ \\
\hline M2WF1 & $19.66^{\mathrm{b}}$ & $17.71^{\mathrm{a}}$ & $0.66^{\text {bcd }}$ & $9.67^{\mathrm{a}}$ \\
\hline M2WF2 & $17.50^{\mathrm{de}}$ & $15.41^{\mathrm{d}-\mathrm{f}}$ & $0.56^{\mathrm{g}}$ & $8.33^{\text {bc }}$ \\
\hline M2WF3 & $15.28^{\mathrm{f}-\mathrm{h}}$ & $16.43^{\mathrm{b}-\mathrm{e}}$ & $0.65^{b-d}$ & $7.33^{\mathrm{c}-\mathrm{f}}$ \\
\hline M2WF4 & $19.72^{\mathrm{b}}$ & $14.96^{\mathrm{f}}$ & $0.63^{\text {cd }}$ & $4.00^{\mathrm{j}-\mathrm{m}}$ \\
\hline M3WF1 & $19.38^{b}$ & $15.10^{\mathrm{f}}$ & $0.55^{\mathrm{g}}$ & $10.33^{\mathrm{a}}$ \\
\hline M3WF2 & $17.33^{\mathrm{e}}$ & $15.32^{\mathrm{ef}}$ & $0.64^{\mathrm{bcd}}$ & $6.33^{\mathrm{e}-\mathrm{h}}$ \\
\hline M3WF3 & $15.45^{\mathrm{fg}}$ & $14.58^{\mathrm{fg}}$ & $0.61^{\mathrm{def}}$ & $6.00^{\mathrm{f}-\mathrm{h}}$ \\
\hline M3WF4 & $15.40^{\mathrm{fg}}$ & $14.80^{\mathrm{f}}$ & $0.68^{\mathrm{ab}}$ & $3.67^{k-n}$ \\
\hline M4WF1 & $17.39^{\mathrm{e}}$ & $13.28^{\mathrm{hi}}$ & $0.62^{\text {de }}$ & $4.00^{\mathrm{j}-\mathrm{m}}$ \\
\hline M4WF2 & $18.89^{\mathrm{bc}}$ & $13.33^{\mathrm{hi}}$ & $0.64^{\mathrm{b}-\mathrm{d}}$ & $4.33^{\mathrm{g}-\mathrm{j}}$ \\
\hline M4WF3 & $15.63^{f}$ & $11.19^{\mathrm{kl}}$ & $0.65^{\mathrm{b}-\mathrm{d}}$ & $5.33^{\mathrm{g}-\mathrm{j}}$ \\
\hline M4WF4 & $15.22^{\mathrm{f}-\mathrm{h}}$ & $12.70^{\mathrm{ij}}$ & $0.68^{\mathrm{a}-\mathrm{c}}$ & $2.33^{\mathrm{n}}$ \\
\hline M5WF1 & $21.33^{\mathrm{a}}$ & $15.61^{\mathrm{c}-\mathrm{f}}$ & $0.65^{b-d}$ & $10.00^{\mathrm{a}}$ \\
\hline M5WF2 & $19.50^{\mathrm{b}}$ & $12.54^{\mathrm{ij}}$ & $0.57^{\mathrm{fg}}$ & $9.33^{\mathrm{ab}}$ \\
\hline M5WF3 & $14.58^{\mathrm{gh}}$ & $13.01^{\mathrm{i}}$ & $0.58^{\mathrm{e}-\mathrm{g}}$ & $5.67^{\mathrm{g}-\mathrm{i}}$ \\
\hline M5WF4 & $21.33^{\mathrm{a}}$ & $10.55^{1}$ & $0.62^{\mathrm{de}}$ & $3.67^{k-n}$ \\
\hline M6WF1 & $16.68^{\mathrm{e}}$ & $17.17^{\mathrm{ab}}$ & $0.63^{\mathrm{cd}}$ & $8.00^{\text {cd }}$ \\
\hline M6WF2 & $18.38^{\mathrm{cd}}$ & $13.41^{\mathrm{hi}}$ & $0.65^{\mathrm{b}-\mathrm{d}}$ & $7.67^{\mathrm{c}-\mathrm{e}}$ \\
\hline M6WF3 & $19.68^{b}$ & $14.56^{\mathrm{fg}}$ & $0.65^{b-d}$ & $2.33^{\mathrm{n}}$ \\
\hline M6WF4 & $13.25^{\mathrm{i}}$ & $12.68^{\mathrm{ij}}$ & $0.623^{\mathrm{de}}$ & $6.33^{\mathrm{e}-\mathrm{h}}$ \\
\hline M7WF1 & $15.56^{\mathrm{f}}$ & $16.48^{\mathrm{b}-\mathrm{d}}$ & $0.64^{b-d}$ & $5.00^{\mathrm{h}-\mathrm{k}}$ \\
\hline M7WF2 & $18.40^{\text {cd }}$ & $16.61^{\mathrm{a}-\mathrm{c}}$ & $0.70^{\mathrm{a}}$ & $4.33^{\mathrm{i}-1}$ \\
\hline M7WF3 & $12.58^{\mathrm{i}}$ & $13.04^{\mathrm{i}}$ & $0.45^{\mathrm{h}}$ & $6.67^{\mathrm{d}-\mathrm{g}}$ \\
\hline M7WF4 & $16.56^{\mathrm{e}}$ & $11.71^{\mathrm{jk}}$ & $0.57^{\mathrm{fg}}$ & $3.33^{1-\mathrm{n}}$ \\
\hline $\mathrm{Cv} \%$ & 3.04 & 4.36 & 4.04 & 13.12 \\
\hline LSD 5\% & 0.85 & 1.02 & 0.04 & 1.24 \\
\hline
\end{tabular}


Mean values followed by the same letter(s) with in a column are not significantly different at $\mathrm{P}<0.05$

$\mathbf{M}_{1}$ - Forest soil , $\mathbf{M}_{2}$ - Top soil, $\mathbf{M}_{3}$ - Forest \& Top soil (1:1, $\mathbf{M}_{4-}$ Forest \& Compost(1:1), M- Top \&

Compost(1:1 ratios), M6- Forest, Top and Compost(1:1:1), M7- Top and Compost 3:1 (control), WF 1 - Watering

Frequency Every day, $\mathrm{WF}_{2}$ - Watering Frequency Every 2 days, $\mathrm{WF}_{3}$ - Watering Frequency Every 3 days , $\mathrm{WF}_{4}$ : Watering Frequency Every 4 days

\subsection{Mean Leaf Area Per Leaf}

The response of Leaf area $\left(\mathrm{cm}^{2}\right)$ to soil media and watering frequency were highly significant ( $\mathrm{p}<0.01)$. The leaf area of seeds sown in top soil and compost mixture in 1:1 ratio and watering frequency every day $\left(\mathrm{M}_{5} \mathrm{WF}_{1}\right)$ was found highest value $24.89 \mathrm{~cm}^{2}$ at four months of growth stages after sowing (Table 1). Similarly, seeds sown in top soil media and watering frequency every day $\left(\mathrm{M}_{2} \mathrm{WF}_{1}\right)$ and seeds sown in a blend of forest soil, top soil and compost in 1:1:1 ratios and watering frequency every two days $\left(\mathrm{M}_{6} \mathrm{WF}_{2}\right)$ exhibited higher mean values $\left(24.78 \mathrm{~cm}^{2}\right)$ and $(24.26$ $\left.\mathrm{cm}^{2}\right)$ at four months of growth stage and lowest leaf area values $\left(13.96 \mathrm{~cm}^{2}\right),\left(13.27 \mathrm{~cm}^{2}\right)$ for seeds sown in forest soil media and watering frequency every four days $\left(\mathrm{M}_{1} \mathrm{WF}_{4}\right)$ and seeds sown in top soil and compost soil media in 3:1 ratios and watering frequency every three days $\left(\mathrm{M}_{7} \mathrm{WF}_{3}\right)$ were recorded.

Contrary to shoot height and girth, which showed rapid increase two months after emergence, rapid leaf area growth was observed a month later i.e. four months after emergence. This could explain that assimilates were available primarily for root development and later on for shoot growth during the period of two months after emergence. In general the growth of above ground parts of korarima seedlings between two months after emergence was very slow but it was rapid after two months after emergence. Such a growth trend indicated that growth of korarima seedlings in the first 2 months after emergence is probably the period of root development and the growth of the above ground plant parts become rapid only when root system is well established. The result coincide with the reports of Tesfaye (2005) more frequent of irrigation resulted in higher rate of shoot growth with greater leaf area and other parts of the seedling, Blum(1996) moisture shortage affects growth and development of crop plants at different stages morphological characters such as leaf area. Plant height and root growth are several affected by less water frequent in many crop plants.

\subsection{Total Leaf Area}

The interaction of soil media and watering frequency was significantly $(\mathrm{P}<0.01)$ affected Total Leaf Area $\left(\mathrm{cm}^{2}\right)$. The highest record was $284.33 \mathrm{~cm}^{2}$ for seeds sown in a blend of forest soil, top soil and compost in 1:1:1 ratio and watering frequency every two days $\left(\mathrm{M}_{6} \mathrm{WF}_{2}\right)$ were recorded for four months of seedling growth stages. while the smallest value (139.84) for seeds sown in a blend of forest soil, top soil and compost soil media in 1:1:1 ratios and watering frequency every four days $\left(\mathrm{M}_{6} \mathrm{WF}_{4}\right)$ and seed sown in forest soil media and watering frequency every 4 days (M1WF4)(139.46 $\mathrm{cm}^{2}$ ) was recorded for four months (Table 1). The reason for better frequent water application could be attributed to the established fact that increase leaf area expansion and thus photosynthetic activity, rooting volume nd efficiency which all contributed to better growth and development. It has been reported that the rate of extension growth of the shoot and total leaf area of seedlings increased as the available soil water increased Meinzer et al., 1992) and also with available soil media nutrient.

\subsection{Leaf Number}

Interaction of soil media and watering frequency were significant different $(\mathrm{p}<0.05)$ on Leaf number. During four months of seedling growth stage, maximum leaf number were recorded from seeds sown in top soil media and watering frequency every day $\left(\mathrm{M}_{2} \mathrm{WF}_{1}\right)(11.33)$, seeds sown in mixture of forest and top soil in 1:1 ratio and watering frequency every day $\left(\mathrm{M}_{3} \mathrm{WF}_{1}\right)(11.17)$, seeds sown in forest soil and compost mixture at 1:1 ratio and watering frequency every day $\left(\mathrm{M}_{4} \mathrm{WF}_{1}\right)(11.17)$, seeds sown in top soil and compost mixture at 1:1 ratio and watering frequency every day $\left(\mathrm{M}_{5} \mathrm{WF}_{1}\right)(11.33)$ and seeds sown in top soil and compost mixture at 3:1 ratio and watering frequency every day $\left(\mathrm{M}_{7} \mathrm{WF}_{1}\right)$ (11.17), followed by (10.67) (Leaf number) were recorded for seeds sown in top soil media and watering frequency every two days $\left(\mathrm{M}_{2} \mathrm{WF}_{2}\right)$, seeds sown in top soil and compost mixture at 1:1 ratio and watering frequency every two days $\left(\mathrm{M}_{5} \mathrm{WF}_{2}\right)$ and seeds sown in top soil and compost mixture at 1:1 ratio and watering frequency every four days $\left(\mathrm{M}_{5} \mathrm{WF}_{4}\right)$, and minimum from seeds sown in forest 
Effect of Potting Media and Watering Frequency on Growth Rate of Seedling of Korarima (Aframomum Cororima (Braun) P.C.M. Jansen) Under Nursery

soil and compost mixture at 1:1 ratio and watering frequency every three days $\left(\mathrm{M}_{4} \mathrm{WF}_{3}\right)(8.5)$ at four months of seedling growth stage, respectively (Table 1).The result indicate frequent watering and most media are convenient for increasing of leaf number. The present finding is in line with that of Simon et al., (2011). Application of water on daily or every other day basis to other for seedling increased the number of leaves, increased height, survival rate and root collar diameter (RCD) of the seedling. In contrast, they have observed that limited application of water had a negative effect on seedling height, RCD and number of leaves produced.

Table2. Interaction effect of soil media and watering frequency on leaf area, leaf number, total leaf area

\begin{tabular}{|c|c|c|c|}
\hline Treatment & Leaf area $\left(\mathrm{cm}^{2}\right)$ & Leaf No. & $\begin{array}{ll}\text { Total } & \text { Leaf } \\
\text { Area }\left(\mathrm{cm}^{2}\right) & \end{array}$ \\
\hline M1WF1 & $19.40^{\mathrm{kl}}$ & $10.33^{\mathrm{bc}}$ & $183.84^{\mathrm{jk}}$ \\
\hline M1WF2 & $22.14^{\text {fgh }}$ & $10.00^{b-d}$ & $215.74^{\mathrm{i}}$ \\
\hline M1WF3 & $16.94^{\mathrm{m}}$ & $9.50^{c-e}$ & $174.43^{\mathrm{k}}$ \\
\hline M1WF4 & $13.96^{\mathrm{n}}$ & $9.00^{\mathrm{ef}}$ & $139.46^{1}$ \\
\hline M2WF1 & $23.00^{\mathrm{d}-\mathrm{f}}$ & $11.33^{\mathrm{a}}$ & $254.21^{\mathrm{c}-\mathrm{e}}$ \\
\hline M2WF2 & $24.78^{\mathrm{ab}}$ & $10.67^{\mathrm{ab}}$ & $250.59^{c-f}$ \\
\hline M2WF3 & $22.88^{\mathrm{d}-\mathrm{f}}$ & $9.50^{c-e}$ & $243.09^{\mathrm{e}-\mathrm{g}}$ \\
\hline M2WF4 & $21.32^{\mathrm{hi}}$ & $10.33^{\mathrm{bc}}$ & $240.62^{e-g}$ \\
\hline M3WF1 & $20.67^{\mathrm{ij}}$ & $11.17^{\mathrm{a}}$ & $226.11^{\text {gh }}$ \\
\hline M3WF2 & $23.77^{b-d}$ & $10.17^{\mathrm{b}-\mathrm{d}}$ & $271.189^{\mathrm{ab}}$ \\
\hline M3WF3 & $19.05^{\mathrm{kl}}$ & $9.67^{\mathrm{cde}}$ & $193.97^{\mathrm{j}}$ \\
\hline M3WF4 & $16.61^{\mathrm{m}}$ & $10.00^{\mathrm{b}-\mathrm{d}}$ & $151.06^{1}$ \\
\hline M4WF1 & $22.59^{\mathrm{e}-\mathrm{g}}$ & $11.17^{\mathrm{a}}$ & $266.71^{\mathrm{bc}}$ \\
\hline M4WF2 & $23.43^{\mathrm{c}-\mathrm{e}}$ & $10.17^{\mathrm{b}-\mathrm{d}}$ & $238.85^{\mathrm{e}-\mathrm{g}}$ \\
\hline M4WF3 & $22.99^{\mathrm{d}-\mathrm{f}}$ & $8.50^{\mathrm{f}}$ & $251.99^{\mathrm{c}-\mathrm{e}}$ \\
\hline M4WF4 & $20.06^{\mathrm{jk}}$ & $10.00^{\mathrm{b}-\mathrm{d}}$ & $190.75^{\mathrm{jk}}$ \\
\hline M5WF1 & $24.89^{\mathrm{a}}$ & $11.33^{\mathrm{a}}$ & $252.02^{\mathrm{c}--}$ \\
\hline M5WF2 & $21.65^{\mathrm{g}-\mathrm{i}}$ & $10.67^{\mathrm{ab}}$ & $248.17^{\text {def }}$ \\
\hline M5WF3 & $23.01^{\mathrm{d}-\mathrm{f}}$ & $10.00^{\mathrm{b}-\mathrm{d}}$ & $234.13^{\mathrm{f}-\mathrm{h}}$ \\
\hline M5WF4 & $22.18^{\mathrm{f}-\mathrm{h}}$ & $10.67^{\mathrm{ab}}$ & $252.23^{\mathrm{c}-\mathrm{e}}$ \\
\hline M6WF1 & $18.77^{1}$ & $10.33^{\mathrm{bc}}$ & $194.60^{j}$ \\
\hline M6WF2 & $24.26^{\mathrm{a}-\mathrm{c}}$ & $9.33 \mathrm{~d}^{\mathrm{e}}$ & $284.33^{\mathrm{a}}$ \\
\hline M6WF3 & $21.01^{\mathrm{ij}}$ & $10.17^{\mathrm{b}-\mathrm{d}}$ & $220.59^{\text {hi }}$ \\
\hline M6WF4 & $19.31^{\mathrm{kl}}$ & $9.33^{\mathrm{de}}$ & $139.84^{1}$ \\
\hline M7WF1 & $23.00^{\mathrm{d}-\mathrm{f}}$ & $11.17^{\mathrm{a}}$ & $246.50^{\mathrm{d}-\mathrm{f}}$ \\
\hline M7WF2 & $23.04^{\mathrm{d}-\mathrm{f}}$ & $9.67^{\mathrm{c}-\mathrm{e}}$ & $263.58^{b-d}$ \\
\hline M7WF3 & $13.27^{\mathrm{n}}$ & $9.00^{\mathrm{ef}}$ & $237.02^{\mathrm{e}-\mathrm{g}}$ \\
\hline M7WF4 & $16.32^{\mathrm{m}}$ & $9.17^{\mathrm{ef}}$ & $183.47^{\mathrm{jk}}$ \\
\hline $\mathrm{Cv} \%$ & 2.92 & 4.23 & 4.13 \\
\hline LSD 5\% & 1.00 & 0.7 & 15.07 \\
\hline
\end{tabular}

Mean values followed by the same letter(s) with in a column are not significantly different at $\mathrm{P}<0.05$

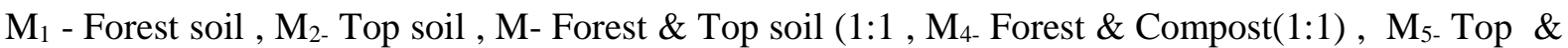

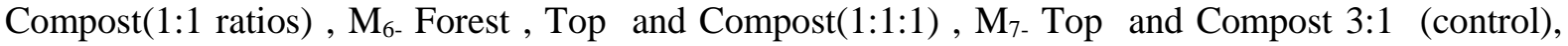
$\mathrm{WF}_{1-}$ Watering Frequency Every day, $\mathrm{WF}_{2}$ - Watering Frequency Every 2 days, $\mathrm{WF}_{3-}$ Watering Frequency Every 3 days , $\mathrm{WF}_{4}$ : Watering Frequency Every 4 days

\subsection{Leaf Dry Weight}

Interaction of soil media and watering frequency on leaf dry weight was highly significant different ( $p<0.01$ ). The response indicating that some had the same response to interaction effects of soil media and watering frequency in dry matter accumulation in their leaf weight $(\mathrm{g})$ for seeds sown in top soil and compost mixture at 3:1 ratio and watering frequency every two days $\left(\mathrm{M}_{7} \mathrm{WF}_{2}\right)$ (1.590) maximum dry weight per plant was recorded at four months growth of seedling stage. Similarly, seeds sown in forest soil media and watering frequency every two days $\left(\mathrm{M}_{1} \mathrm{WF}_{2}\right)$, seeds sown in top soil media and watering frequency every three days $\left(\mathrm{M}_{2} \mathrm{WF}_{3}\right)$ and seeds sown in top soil and compost mixture at 1:1 ratio and watering frequency every three days $\left(\mathrm{M}_{5} \mathrm{WF}_{3}\right)$ exhibited higher mean values $(1.303 \mathrm{~g}),(1.283 \mathrm{~g})$ and $(1.403 \mathrm{~g})$ at four months growth of seedling stage, while seeds sown in top soil 
and compost mixture at 3:1 ratio and watering frequency every four days $\left(\mathrm{M}_{7} \mathrm{WF}_{4}\right)$ showed the minimum value of $(0.527 \mathrm{~g})$ (Table 2$)$. The minimum value observed was because of the soil less frequent irrigated and also physical and chemical character of the soil medium support the watering frequency of one and two days interval. While at growth stage increase the frequency of the water may decrease at normal condition. The finding similar with work of Tesfaye et al., (2005) frequent watering resulted in higher rate of shoot growth with greater leaf area stem diameter, leaf and stem dry weight and height of seedlings.

\subsection{Stem Dry Weight}

Interaction of soil media and watering frequency on stem dry weight $(\mathrm{g})$ were highly significant different $(\mathrm{p}<0.01)$ observed and relatively maximum stem dry weight per plant were recorded from seeds sown in top soil and compost mixture at 3:1 ratio and watering frequency every two days $\left(\mathrm{M}_{7} \mathrm{WF}_{2}\right) 0.827 \mathrm{~g}$, and minimum values from seeds sown in top soil and compost mixture at 3:1 ratio and watering frequency every four days $\left(\mathrm{M}_{7} \mathrm{WF}_{4}\right)(0.230 \mathrm{~g})$ (Table 2). This finding is observed due to forest soil media alone with applying daily watering frequency up to two months increase the weight of leaf and stem but after this stage the media not increase the weight even though the frequency as it is, this may be due to nutrient content of the media. On the other hand, media with compost soil combination shown weight increase. This finding similar with work of Simon A et al., (2011) Considering water availability, labor costs and time involved and based on the present results, nursery to irrigate korarima seedlings every two days or three days interval with compost soil combination under the prevailing conditions. This is because seedlings under different environmental conditions may have different water requirement. The result coincide with finds of report Naples et al., (1990) dry matter accumulation in the stem and leaves were consistently reduced as the supply of water to the seedlings decreased

\subsection{Root Dry Weight}

Interaction of soil media and watering frequency on root dry weight was differed significantly $(\mathrm{p}<$ 0.01 ). Among the treatments tested, highest root weight per seedling were recorded from seeds sown in forest soil and compost mixture at 1:1 ratio and watering frequency every two days $\left(\mathrm{M}_{4} \mathrm{WF}_{2}\right)$ and seeds sown in a blend of forest soil, top soil and compost in 1:1:1 ratio and watering frequency every two days $\left(\mathrm{M}_{6} \mathrm{WF}_{2}\right)$ treatments, which were $0.633 \mathrm{~g}$ and $0.600 \mathrm{~g}$ at four months of growth stages. On the other hand, the seeds sown in top soil and compost mixture at 3:1 ratio and watering frequency every four days $\left(\mathrm{M}_{7} \mathrm{WF}_{4}\right)$ gave the lowest root weight during the growth stages of four months and the value was $0.093 \mathrm{~g}$ at four months of growth stages (Table 2). From the result obtained with blended soil media due to watering frequency increase the dry matter of the root was increased with less watering frequency the root dry weight decreased..The result similar with work of Mohammed (2004) growth and the distribution of the root of coffee seedling expressed as root length and root density and root weight were further enhanced by water frequency of water but decreased with limited supply. The adverse effect of water stress and nutrient supply on root growth and dry weight of roots has also been observed on different crops (Naples et al., 1990).

\subsection{Total Dry Weight}

The interaction of soil media and watering frequency on weight $(\mathrm{g})$ of total dry weight per seedling showed highly significant $(\mathrm{P}<0.01)$ variations. The highest mean value of total dry weight $(\mathrm{g})(3.47)$ was recorded for seeds sown in top soil and compost mixture at 3:1 ratio and watering frequency every two days $\left(\mathrm{M}_{7} \mathrm{WF}_{2}\right)$. The lowest value recorded was $1.07(\mathrm{~g})$ for seeds sown in top soil and compost mixture at 3:1 ratios and watering frequency every four days $\left(\mathrm{M}_{7} \mathrm{WF}_{4}\right)$ at four months of growth stage (Table 2 ). In general, all the treatments showed an increase in total dry matter accumulation during the fourth month's period with unequal increasing rate among the treatments observed. The total dry matter increment after two months period was highest (more than $3 \mathrm{~g}$ ) for the $\mathrm{M}_{7} \mathrm{WF}_{2}$ (seeds sown in top soil and compost mixture at 3:1 ratio and watering frequency every two days) except for $\mathrm{M}_{7} \mathrm{WF}_{4}$ (seeds sown in top soil and compost mixture at 3:1 ratio and watering frequency every four days), which showed total dry weight gm per plant increment of 3.47 and $1.07 \mathrm{~g}$. The results are in agreement with those of Cannel (1985) who reported that total dry weight $(\mathrm{g})$ increment of coffee was greater during the rainy season as well as of Guridi et al., (1987) who observed higher total dry matter production at around 80 to $100 \%$ field capacity than at lower soil 
Effect of Potting Media and Watering Frequency on Growth Rate of Seedling of Korarima (Aframomum Cororima (Braun) P.C.M. Jansen) Under Nursery

water contents. However, the observations made by Tilahun and Schubert (2001) for haricot bean and chickpea, and by Zenebe (2000) for cowpea are contrary to the results of this investigation.

Table3. Interaction effects of soil media and watering frequency on dry wt of leaf, stem and root

\begin{tabular}{|c|c|c|c|c|}
\hline Treatment & Leaf dry wt(g) & stem dry wt $(\mathrm{g})$ & Root dry wt(g) & Total dry wt(g) \\
\hline M1WF1 & $1.000^{\mathrm{c}-\mathrm{g}}$ & $0.417^{\mathrm{f}-\mathrm{i}}$ & $0.453^{\mathrm{b}-\mathrm{d}}$ & $1.94^{\mathrm{f}-1}$ \\
\hline M1WF2 & $1.303^{\mathrm{a}-\mathrm{c}}$ & $0.713^{\mathrm{bc}}$ & $0.470^{\mathrm{bc}}$ & $2.74^{\mathrm{bc}}$ \\
\hline M1WF3 & $0.870^{\mathrm{e}-\mathrm{i}}$ & $0.443^{\mathrm{e}-\mathrm{g}}$ & $0.320^{\mathrm{f}-\mathrm{h}}$ & $1.72^{\mathrm{i}-\mathrm{n}}$ \\
\hline M1WF4 & $0.710^{\mathrm{g}-\mathrm{j}}$ & $0.263^{\mathrm{jk}}$ & $0.290^{\mathrm{g}-\mathrm{i}}$ & $1.40^{\mathrm{m}-\mathrm{o}}$ \\
\hline M2WF1 & $1.003^{\mathrm{c}-\mathrm{g}}$ & $0.463^{\mathrm{e}-\mathrm{g}}$ & $0.367^{\mathrm{d}-\mathrm{g}}$ & $1.95^{\mathrm{e}-1}$ \\
\hline M2WF2 & $0.983^{\mathrm{c}-\mathrm{g}}$ & $0.433^{\mathrm{e}-\mathrm{h}}$ & $0.437^{\text {b-e }}$ & $2.00^{\mathrm{e}-1}$ \\
\hline M2WF3 & $1.283^{\mathrm{a}-\mathrm{d}}$ & $0.633^{\mathrm{cd}}$ & $0.313^{\mathrm{f}-\mathrm{i}}$ & $2.45^{\mathrm{b}-\mathrm{e}}$ \\
\hline M2WF4 & $1.157^{\mathrm{b}-\mathrm{e}}$ & $0.477^{\text {ef }}$ & $0.300^{\mathrm{g}-\mathrm{i}}$ & $2.05^{\mathrm{e}-\mathrm{i}}$ \\
\hline M3WF1 & $0.950^{\mathrm{d}-\mathrm{h}}$ & $0.517^{\mathrm{e}}$ & $0.283^{\mathrm{g}-\mathrm{i}}$ & $1.86^{\mathrm{g}-\mathrm{m}}$ \\
\hline M3WF2 & $1.147^{\mathrm{b}-\mathrm{f}}$ & $0.500^{\mathrm{ef}}$ & $0.493^{\mathrm{b}}$ & $2.39^{\mathrm{c}-\mathrm{f}}$ \\
\hline M3WF3 & $0.75^{\mathrm{g}-\mathrm{j}}$ & $0.343^{\mathrm{h}-\mathrm{j}}$ & $0.350^{\mathrm{e}-\mathrm{g}}$ & $1.59^{\mathrm{j}-\mathrm{n}}$ \\
\hline M3WF4 & $0.630^{\mathrm{h}-\mathrm{j}}$ & $0.333^{\mathrm{ij}}$ & $0.220^{\mathrm{ij}}$ & $1.31^{\mathrm{no}}$ \\
\hline M4WF1 & $1.193^{\mathrm{b}-\mathrm{e}}$ & $0.493^{\mathrm{ef}}$ & $0.337^{\text {f-h }}$ & $2.13^{\mathrm{e}-\mathrm{i}}$ \\
\hline M4WF2 & $0.777^{\mathrm{g}-\mathrm{j}}$ & $0.610^{\mathrm{d}}$ & $0.633^{\mathrm{a}}$ & $2.66^{\mathrm{b}-\mathrm{d}}$ \\
\hline M4WF3 & $0.747^{\mathrm{g}-\mathrm{j}}$ & $0.450^{\mathrm{e}-\mathrm{g}}$ & $0.243^{\mathrm{hi}}$ & $1.64^{\mathrm{i}-\mathrm{n}}$ \\
\hline M4WF4 & $0.813^{\mathrm{f}-\mathrm{j}}$ & $0.420^{\mathrm{e}-\mathrm{i}}$ & $0.347^{\mathrm{e}-\mathrm{g}}$ & $1.72^{\mathrm{i}-\mathrm{n}}$ \\
\hline M5WF1 & $1.137^{b-f}$ & $0.640^{\mathrm{cd}}$ & $0.490^{\mathrm{b}}$ & $2.71^{\mathrm{bc}}$ \\
\hline M5WF2 & $1.180^{\mathrm{b}-\mathrm{e}}$ & $0.767^{\mathrm{ab}}$ & $0.413^{b-f}$ & $2.92^{\mathrm{b}}$ \\
\hline M5WF3 & $1.403^{\mathrm{ab}}$ & $0.477^{\text {ef }}$ & $0.283^{\mathrm{g}-\mathrm{i}}$ & $2.30^{\mathrm{c}-\mathrm{g}}$ \\
\hline M5WF4 & $1.040^{\mathrm{e}-\mathrm{g}}$ & $0.377^{\mathrm{g}-\mathrm{i}}$ & $0.350^{\mathrm{e}-\mathrm{g}}$ & $1.98^{\mathrm{e}-\mathrm{k}}$ \\
\hline M6WF1 & $0.697^{\mathrm{g}-\mathrm{j}}$ & $0.347^{\mathrm{h}-\mathrm{j}}$ & $0.347^{\mathrm{e}-\mathrm{g}}$ & $1.53^{\mathrm{k}-\mathrm{b}}$ \\
\hline M6WF2 & $1.24^{\mathrm{b}-\mathrm{d}}$ & $0.737^{\mathrm{b}}$ & $0.600^{\mathrm{a}}$ & $2.75^{\mathrm{bc}}$ \\
\hline M6WF3 & $1.267^{\mathrm{b}-\mathrm{d}}$ & $0.463^{\mathrm{e}-\mathrm{g}}$ & $0.303^{\mathrm{g}-\mathrm{i}}$ & $2.20^{\mathrm{d}-\mathrm{h}}$ \\
\hline M6WF4 & $0.737^{\mathrm{g}-\mathrm{j}}$ & $0.270^{\mathrm{jk}}$ & $0.35^{\mathrm{e}-\mathrm{g}}$ & $1.47^{1-\mathrm{o}}$ \\
\hline M7WF1 & $1.220^{\mathrm{b}-\mathrm{d}}$ & $0.463^{\mathrm{e}-\mathrm{g}}$ & $0.380^{\mathrm{c}-\mathrm{g}}$ & $2.40^{\mathrm{c}-\mathrm{f}}$ \\
\hline M7WF2 & $1.590^{\mathrm{a}}$ & $0.827^{\mathrm{a}}$ & $0.477^{\mathrm{b}}$ & $3.47^{\mathrm{a}}$ \\
\hline M7WF3 & $0.557^{\mathrm{ij}}$ & $0.473^{\text {ef }}$ & $0.093^{\mathrm{k}}$ & $1.26^{\mathrm{no}}$ \\
\hline M7WF4 & $0.527^{\mathrm{j}}$ & $0.230^{\mathrm{k}}$ & $0.147^{\mathrm{jk}}$ & $1.07^{\circ}$ \\
\hline $\mathrm{Cv} \%$ & 17.67 & 10.28 & 14.38 & 12.68 \\
\hline LSD 5\% & 0.29 & 0.18 & 0.08 & 0.8 \\
\hline
\end{tabular}

Mean values followed by the same letter(s) with in a column are not significantly different at $\mathrm{P}<0.05$

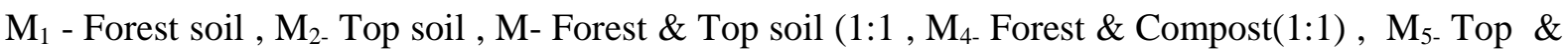

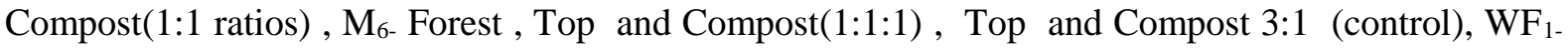
Watering Frequency Every day, $\mathrm{WF}_{2}$ - Watering Frequency Every 2 days, $\mathrm{WF}_{3}$ - Watering Frequency Every 3 days , $\mathrm{WF}_{4}$ : Watering Frequency Every 4 days

\subsection{Growth Rate Components (Growth Indices)}

The interaction of soil media and watering frequency showed highly significant $\mathrm{P}<0.01$ ) difference in Relative Growth Rate (RGR), Absolute Growth Rate(AGR), Net Assimilate Rate(NAR), Leaf Area Ratio(LAR), Specific Leaf Area(SLA) and Leaf Weight Ratio(LWR). The data showed that different interaction of soil media and watering frequency had highly significant $(\mathrm{P}<0.01)$ effect on seedling relative growth rate (RGR) (Table 3). Mean values given in table 16 showed that the highest RGR $(0.29 \mathrm{~g} / \mathrm{g} / \mathrm{d})$ was recorded in soil mixture of top and compost $(3: 1)$ and watering frequency every three days(M7WF3). A minimum value for seedling relative growth rate (RGR) $(0.119 \mathrm{~g} / \mathrm{g} / \mathrm{d})$ was observed in soil mixture of forest, top and compost soil and watering frequency every four days $(1: 1: 1)$ $\left(\mathrm{M}_{6} \mathrm{WF}_{4}\right)$.. Among the treatments tested, the highest AGR per plant was recorded from soil mixture of top and compost (3:1) and watering frequency every two days $\left(\mathrm{M}_{5} \mathrm{WF}_{2}\right)$ the value which was $0.056 \mathrm{~g} / \mathrm{d}$ at four months of growth stages. On the other hand, soil mixture of top and compost (1:1) and watering frequency every four days $\left(\mathrm{M}_{5} \mathrm{WF}_{4}\right)$ gave the lowest value $(0.018 \mathrm{~g} / \mathrm{d})$ of AGR. Korarima seeds soil mixture of top and compost (3:1) and watering frequency every two days $\left(\mathrm{M}_{7} \mathrm{WF}_{2}\right)$ gave the highest NAR $0.0024 \mathrm{~g} / \mathrm{cm}^{2} /$ day, at four months of growth stages after sowing. Korarima seeds sown in top soil and compost in 3:1 ratios and watering frequency every four days $\left(\mathrm{M}_{7} \mathrm{WF}_{4}\right)$.gave the lowest 
Net Assimilate Rate during the growth stages of four months growth stages with their respective values of $0.0011 \mathrm{~g} / \mathrm{cm}^{2} /$ day (Table 3). The interaction of soil media and watering frequency was highly significant $(\mathrm{P}<0.01)$ for leaf area ratio. The highest value $\left(190.85 \mathrm{~cm}^{2} / \mathrm{g}\right)$ of LAR was observed for Korarima seeds sown in top soil and compost in 3:1 ratio and watering frequency every three days $\left(\mathrm{M}_{7} \mathrm{WF}_{3}\right)$. While the lowest value $\left(79.17 \& 77.86 \mathrm{~cm}^{2} / \mathrm{g}\right)$ was recorded for for Korarima seeds sown in forest soil and watering frequency every two days $\left(\mathrm{M}_{1} \mathrm{WF}_{2}\right)$ and Korarima seeds sown in top soil and compost in 3:1 ratio and watering frequency every two days $\left(\mathrm{M}_{7} \mathrm{WF}_{2}\right)$, respectively. Antunez et al. (2001) seems to support this by inferring that temporal variation in RGR within species was due mainly to variation in NAR.

Specific Leaf area was significantly affected by the interaction of soil media and watering frequency (Table 3). The highest SLA $\left(446.45 \mathrm{~cm}^{2} / \mathrm{g}\right)$ was obtained from for Korarima seeds sown in top soil and compost in 3:1 ratios and watering frequency every three days $\left(\mathrm{M}_{7} \mathrm{WF}_{3}\right)$. The minimum SLA was $166.72 \& 166.32 \mathrm{~cm}^{2} / \mathrm{g}$ for Korarima seeds sown in top soil and compost in 3:1 ratios and watering frequency every two days $\left(\mathrm{M}_{4} \mathrm{WF}_{2}\right)$.and for Korarima seeds sown in forest soil and watering frequency every two days $\left(\mathrm{M}_{1} \mathrm{WF}_{2}\right)$, respectively (Table 3 ). Leaf weight ratio was significantly affected by the interaction of soil media and watering frequency. The highest LWR $(0.60 \mathrm{~g} / \mathrm{g})$ was obtained for Korarima seeds sown in top soil and compost in 1:1 ratios and watering frequency every three days $\left(\mathrm{M}_{5} \mathrm{WF}_{3}\right)$. The minimum LWR were $0.29 \mathrm{~g} / \mathrm{g}$ for Korarima seeds sown in forest soil and compost in 1:1 ratios and watering frequency every two days $\left(\mathrm{M}_{4} \mathrm{WF}_{2}\right.$ (Table 3)

The specific leaf mass, SLM is the reciprocal of SLA. Accordingly, the dry matter accumulation in leaves per unit leaf area (SLM) continuously increased with an increasing rate as soil water stress and stress recovery periods increased. This may be accounted for growth reduction due to its inverse relationship to relative growth rate. The increase in SLM during the stress periods may also be due to increase in leaf thickness and reduction of leaf area extension. Similarly, a $10 \%$ change in leaf thickness of 20 species due to drought stress was also reported

Table4. Interaction of media and watering frequency on growth component of Korarima seedling at four months after sowing

\begin{tabular}{|c|c|c|c|c|c|c|}
\hline Treatment & RGR & AGR & NAR & LAR & SLA & LWR \\
\hline M1WF1 & $0.154 \mathrm{ij}$ & $0.032 \mathrm{f}-1$ & $0.0016 \mathrm{~d}-\mathrm{h}$ & $94.57 \mathrm{e}-\mathrm{i}$ & $183.9 \mathrm{ef}$ & $0.51 \mathrm{~b}-\mathrm{e}$ \\
\hline M1WF2 & $0.160 \mathrm{~g}-\mathrm{j}$ & $0.045 b c$ & $0.0020 \mathrm{cb}$ & $79.17 \mathrm{i}$ & $166.32 \mathrm{f}$ & $0.48 \mathrm{~d}-\mathrm{g}$ \\
\hline M1WF3 & $0.168 \mathrm{e}-\mathrm{i}$ & $0.028 \mathrm{~h}-\mathrm{n}$ & $0.0016 \mathrm{~d}-\mathrm{h}$ & $102.29 \mathrm{c}-\mathrm{i}$ & $201.7 \mathrm{ef}$ & $0.51 \mathrm{~b}-\mathrm{e}$ \\
\hline M1WF4 & $0.164 f-j$ & $0.023 \mathrm{~m}-\mathrm{o}$ & $0.0016 \mathrm{~d}-\mathrm{h}$ & $100.12 \mathrm{c}-\mathrm{i}$ & $196.02 \mathrm{ef}$ & $0.51 \mathrm{~b}-\mathrm{e}$ \\
\hline M2WF1 & $0.180 \mathrm{~b}-\mathrm{f}$ & $0.032 \mathrm{f}-1$ & $0.0014 \mathrm{~g}-\mathrm{k}$ & $130.5 \mathrm{c}$ & $255.07 \mathrm{~d}-\mathrm{f}$ & $0.51 \mathrm{~b}-\mathrm{e}$ \\
\hline M2WF2 & $0.166 e-j$ & $0.033 \mathrm{e}-\mathrm{k}$ & $0.0013 \mathrm{~h}-1$ & $125.52 \mathrm{c}-\mathrm{e}$ & $254.85 \mathrm{~d}-\mathrm{f}$ & $0.49 \mathrm{c}-\mathrm{g}$ \\
\hline M2WF3 & $0.174 \mathrm{c}-\mathrm{h}$ & $0.040 \mathrm{~b}-\mathrm{e}$ & $0.0017 \mathrm{c}-\mathrm{f}$ & $101.24 \mathrm{c}-\mathrm{i}$ & $196.85 \mathrm{ef}$ & $0.52 b-d$ \\
\hline M2WF4 & $0.186 b-d$ & $0.034 \mathrm{e}-\mathrm{j}$ & $0.0016 \mathrm{e}-\mathrm{i}$ & $118.94 \mathrm{c}-\mathrm{g}$ & 213.27d-f & $0.56 \mathrm{a}-\mathrm{c}$ \\
\hline M3WF1 & $0.178 \mathrm{~b}-\mathrm{g}$ & $0.030 \mathrm{~g}-\mathrm{m}$ & $0.0015 \mathrm{f}-\mathrm{k}$ & $122.24 \mathrm{c}-\mathrm{f}$ & $237.78 \mathrm{~d}-\mathrm{f}$ & $0.51 \mathrm{~b}-\mathrm{e}$ \\
\hline M3WF2 & $0.187 b-d$ & $0.039 \mathrm{c}-\mathrm{f}$ & $0.0016 \mathrm{~d}-\mathrm{h}$ & $114.27 \mathrm{c}-\mathrm{h}$ & $237.66 \mathrm{~d}-\mathrm{f}$ & $0.48 \mathrm{~d}-\mathrm{g}$ \\
\hline M3WF3 & $0.166 e-j$ & $0.026 \mathrm{j}-\mathrm{n}$ & $0.0014 \mathrm{~h}-1$ & $125.58 \mathrm{c}-\mathrm{e}$ & $271.43 \mathrm{~d}-\mathrm{f}$ & $0.47 \mathrm{~d}-\mathrm{h}$ \\
\hline M3WF4 & $0.149 \mathrm{j}$ & $0.021 \mathrm{no}$ & $0.0013 \mathrm{i}-1$ & $117.28 \mathrm{c}-\mathrm{g}$ & $247.33 \mathrm{~d}-\mathrm{f}$ & $0.48 \mathrm{~d}-\mathrm{g}$ \\
\hline M4WF1 & $0.193 b$ & $0.035 \mathrm{e}-\mathrm{i}$ & $0.0015 \mathrm{e}-\mathrm{j}$ & $125.2 \mathrm{c}-\mathrm{e}$ & $223.93 \mathrm{~d}-\mathrm{f}$ & $0.56 a-c$ \\
\hline M4WF2 & $0.167 \mathrm{e}-\mathrm{i}$ & $0.043 \mathrm{~b}-\mathrm{d}$ & $0.0019 \mathrm{~b}-\mathrm{d}$ & $89.91 \mathrm{~g}-\mathrm{i}$ & $317.33 b-d$ & $0.29 \mathrm{i}$ \\
\hline M4WF3 & $0.179 \mathrm{~b}-\mathrm{g}$ & $0.027 \mathrm{i}-\mathrm{n}$ & $0.0012 \mathrm{kl}$ & $158.72 \mathrm{~b}$ & $372.72 \mathrm{a}-\mathrm{c}$ & $0.44 \mathrm{e}-\mathrm{h}$ \\
\hline M4WF4 & $0.156 \mathrm{~h}-\mathrm{j}$ & $0.028 \mathrm{i}-\mathrm{n}$ & $0.0014 \mathrm{~g}-\mathrm{k}$ & $111.07 \mathrm{c}-\mathrm{h}$ & $234.09 \mathrm{~d}-\mathrm{f}$ & $0.48 \mathrm{~d}-\mathrm{g}$ \\
\hline M5WF1 & $0.166 e-j$ & $0.044 \mathrm{~b}-\mathrm{d}$ & $0.0018 \mathrm{c}-\mathrm{e}$ & 92.94f-i & $222.28 \mathrm{~d}-\mathrm{f}$ & $0.42 \mathrm{gh}$ \\
\hline M5WF2 & $0.188 \mathrm{bc}$ & $0.048 \mathrm{~b}$ & $0.0022 \mathrm{ab}$ & 85.3hi & $212.63 \mathrm{~d}-\mathrm{f}$ & $0.40 \mathrm{~h}$ \\
\hline M5WF3 & $0.167 \mathrm{e}-\mathrm{i}$ & $0.038 \mathrm{c}-\mathrm{g}$ & $0.0016 \mathrm{~d}-\mathrm{h}$ & $103.93 \mathrm{c}-\mathrm{i}$ & $174.93 \mathrm{ef}$ & $0.60 \mathrm{a}$ \\
\hline M5WF4 & $0.187 b-d$ & $0.033 \mathrm{e}-\mathrm{k}$ & $0.0014 \mathrm{f}-\mathrm{k}$ & $128.21 \mathrm{~cd}$ & $245.38 \mathrm{e}-\mathrm{f}$ & $0.52 b-d$ \\
\hline M6WF1 & $0.169 \mathrm{~d}-\mathrm{i}$ & $0.025 \mathrm{k}-0$ & $0.0013 \mathrm{~h}-1$ & $128.26 \mathrm{~cd}$ & $282.21 \mathrm{c}-\mathrm{e}$ & $0.46 \mathrm{~d}-\mathrm{h}$ \\
\hline M6WF2 & $0.193 b$ & $0.045 b c$ & $0.0019 b-d$ & $103.71 \mathrm{c}-\mathrm{i}$ & $229.32 d-f$ & $0.45 \mathrm{~d}-\mathrm{h}$ \\
\hline M6WF3 & $0.173 \mathrm{c}-\mathrm{h}$ & $0.036 \mathrm{~d}-\mathrm{h}$ & $0.0017 \mathrm{~d}-\mathrm{g}$ & $101.44 \mathrm{c}-\mathrm{i}$ & $177.3 \mathrm{ef}$ & $0.57 \mathrm{ab}$ \\
\hline M6WF4 & $0.119 \mathrm{k}$ & $0.0241-\mathrm{o}$ & $0.0012 \mathrm{j}-1$ & $96.91 \mathrm{~d}-\mathrm{i}$ & $198.99 \mathrm{ef}$ & $0.50 \mathrm{~b}-\mathrm{f}$ \\
\hline M7WF1 & $0.176 \mathrm{~b}-\mathrm{g}$ & $0.039 \mathrm{c}-\mathrm{f}$ & $0.0017 \mathrm{~d}-\mathrm{g}$ & $103.58 \mathrm{c}-\mathrm{i}$ & $204.99 \mathrm{ef}$ & $0.50 \mathrm{~b}-\mathrm{f}$ \\
\hline M7WF2 & $0.188 b c$ & $0.056 \mathrm{a}$ & $0.0024 \mathrm{a}$ & $77.86 \mathrm{i}$ & $166.72 \mathrm{f}$ & $0.47 \mathrm{~d}-\mathrm{h}$ \\
\hline M7WF3 & $0.29 \mathrm{a}$ & $0.021 \mathrm{no}$ & $0.0016 \mathrm{e}-\mathrm{i}$ & $190.85 a$ & $446.45 a$ & $0.44 \mathrm{f}-\mathrm{h}$ \\
\hline
\end{tabular}


Effect of Potting Media and Watering Frequency on Growth Rate of Seedling of Korarima (Aframomum Cororima (Braun) P.C.M. Jansen) Under Nursery

\begin{tabular}{|l|l|l|l|l|l|l|}
\hline M7WF4 & $0.183 \mathrm{~b}-\mathrm{e}$ & $0.018 \mathrm{o}$ & 0.00111 & $180.83 \mathrm{ab}$ & $388.78 \mathrm{ab}$ & $0.48 \mathrm{~d}-\mathrm{g}$ \\
\hline Cv\% & 5.36 & 12.80 & 12.44 & 13.98 & 22.73 & 7.70 \\
\hline LSD 5\% & 0.02 & 0.01 & 0.0003 & 26.23 & 89.70 & 0.06 \\
\hline
\end{tabular}

Mean values followed by the same letter(s) with in a column are not significantly different at $\mathrm{P}<0.05$

$\mathbf{M}_{1}$ - Forest soil , $\mathbf{M}_{2}$ - Top soil , $\mathbf{M}_{3}$ - Forest \& Top soil (1:1, $\mathbf{M}_{4}$ - Forest \& Compost(1:1), $\mathbf{M}_{5 \text { - }}$ Top \&

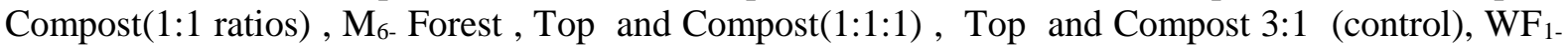
Watering Frequency Every day, $\mathrm{WF}_{2}$ - Watering Frequency Every 2 days, $\mathrm{WF}_{3}$ - Watering Frequency Every 3 days, $\mathrm{WF}_{4}$ : Watering Frequency Every 4 days

RGR - relative growth rate, AGR-absolute growth rate, NAR-net assimilate rate, SLA-specific leaf area , LWR- Leaf weight ratio, LAR- leaf area ratio

\section{CONCLUSION}

From the present results of this study it can be concluded that soil media and watering frequency improved growth parameters, dry weight and relative growth rate. The ANOVA indicated that there was a significant variation among the different growth media and watering frequency of Afframomum korarima seedling. Highly significant $(p<0.01)$ variation was obtained among the treatments in terms of growth parameters, dry weight and relative growth rate .

\section{REFERENCES}

[1] Adjet-Twum, D. and L. Solomon, 1982. Some Research Methods in Agronomy and Crop Physiology. Institute of Agricultural Research, Addis Ababa, Ethiopia.

[2] Antunez, I., Retamosa, E. C., \& Villar, R. (2001). Relative growth rate in phylogenetically related deciduous and evergreen woody species. Oecologia, 128, 172- 180. http://dx.doi.org/10.1007/s004420100645

[3] Baiyeri KP., and Mbah BN.2006. Effects of soilless and soil based nursery media on seedling emergence, growth and response to water stress of African breadfruit (Treculia Africana Decne). African Journal of Biotechnology, 5: 1405-1410.

[4] Baiyeri KP.2005. Response of Musa Species to Macro-Propagation: II: The effects of genotype, initiation and weaning media on sucker growth and quality in the nursery. Afr. J. Biotechnol. 4(3): 229-234.

[5] Bernard R. and François V., 2003. "Natural patrimony and local communities in Ethiopia: geographical advantages and limitations of a system of indications" 29th Annual Spring Symposium of Centre for African Studies.

[6] Blum A.1996 Crop response to drought and the interpretation of adaptation. Plant Growth Regulation 20: 135-148.

[7] Braun A., 2011. Aframomum corrorima was published in Spices, Condiments and Medicinal Plants in Ethiopia,Their Taxonomy and Agricultural Significance. National Germplasm Resources Laboratory, Beltsville,Maryland: USDA, ARS, National Genetic Resources Program. Retrieved June 19, 2011. Synonyms:

[8] Cannel, M. G. R. 1985. Physiology of the coffee crop. pp.108-134. In: Clifford, M. N. and Willson, K. C. (eds.) Coffee botany, biochemistry and production of beans and beverage. Croom Helm, London, England.

[9] Concentration in nine boreal tree species differing in relative growth rate. Functional Ecology 12, 395405.

[10] Cornelissen, J. H. C., Castro-Díez, P., \& Carnelli, A. C. (1998). Variation in relative growth rate among woody species: scaling up. In H. Lambers, H. Poorter, \& M van. Vuuren (Eds.), Inherent variation in plant growth:physiological mechanisms and ecological consequences (pp. 363-392). Backhuys, Leiden.early Seedling Growth of Picralima nitida (Stapf).Sustainable Agriculture Research; Vol. 3,

[11] Gbadamosi Alaba Emmanuel1.2014.Effect of Watering Regimes and Water Quantity on the early Seedling Growth of Picralima nitida (Stapf).Sustainable Agriculture Research; Vol. 3, No. 2

[12] Guridi, F., D. Mornales, F. Soto, R. Valdes and H. Vento.1987. Some aspects of coffee physiology in Cuba. ASIC: association Scientifique Internationale du Café.12th International Scientific Colloquium on coffee, 29 June-3 July 1987, Montreux, 2:501-509.

[13] H. MirseyedHosseini, E. Alavipoor, M. Delshad.2017. Evaluation of different growth media for tomato seedlings to optimize production and water use. Iran Agricultural Research. 36(2) 61-70

[14] Hartmann H. T., Kester, D . E. Davies, F. T., and Genve, R. I., 2007. Hartmann and Kester's plant propagation, principles and practices. Seventh edition. Prentice-Hall of India Private limited pp880. 
[15] Hunt R. 1990. Basic growth analysis. London: Unwin Hyman. IAR. 1996. Recommended production technologies for coffee and associated crops. IAR, Addis Ababa. 18p

[16] Jansen PCM .2002. Aframomum corrorima (Braun) P.C.M. Jansen. Record from protabase. In: Oyen LPA, Lemmens RHMJ (eds) PROTA (Plant Resources of Tropical Africa/Ressources végétales de l'Afrique tropicale). Wageningen, The Netherlands

[17] Meinzer, F.C., Saliendra, N.Z., and C.H.Crisostc. 1992.Cabon isotope discrimination and gas exchange in Coffee Arabica during adjustment to different soil moisture regimes.Australian Journal of plant physiology vol. 19 No. 2: 171-184.

[18] Modality, plant per punch and irrigation on 'CATURRA ROJO' production. I Groeth. Cienciay Tecnica en la. AGRICULTURA CAFÉ Y CACAO v. 12 No. 1-2 :41-49.

[19] Mohammed worku .2004. Rresponse of seedlings of Arabica coffee (Coffea arabica 1.) cultivars to soil water deficit.. An M. Sc. Thesis Presented to Graduate Studies of Alemaya_ university, Alemaya, Ethiopia

[20] Mohammedsani Zakir.2018. Review on Korarima (Aframomum Corrorima (Braun) P.C.M. Jansen) Research Achievements, Challenges and Future Prospective in Ethiopia. International Journal of Research Studies in Agricultural Sciences. Volume 4, Issue 1, PP 29-36

[21] Napoles, S. ; Tabares, G. ; Mendez, E. and B. Cuba. 1990. Effect of shade and sun light No. 2

[22] Poorter, H. \& Lambers,H. 1991. Is interspecific variation in relative growth rate positively correlated with biomass allocation to the leaves? American Naturalist 138:1264-1268.

[23] Reich, P.B., Walters, M.B., Tjoelker, M.G., Vanderklein, D.W. \& Buschena, C. (1998) Photosynthesis and respiration rates depend on leaf and root morphology and nitrogen

[24] SAS (Statistical Analysis System), 2008. (Version 9.2). SAS Institute, Cary, NC. USA.

[25] Simon A. Mng'omba1, Festus K. Akinnifesi1, Gudeta Sileshi1, Oluyede C. Ajayi1, Betserai I. Nyoka1 and Ramni Jamnadass.2011. Water application rate and frequency affect seedling survival and growth of Vangueria infausta and Perseaamericana: African Journal of Biotechnology Vol. 10(9).

[26] Taye K, S. Tesfaye and Y.Alemseged. 2008. Influence of Media mixture, watering frequency on seed germination and seedling growth of Arabia coffee in Ethiopia.. In: Girma Adugna, Bayetta Belachew, Tesfaye Shimber, Endale Taye and Taye Kufa (eds.).In: Proceedings of a national work shop, four decade and development Ethiopia 14-17 August 2007, Addis Ababa (Ghion Hotel), Ethiopia. pp. 307-316.

[27] Tesfaye, S.G.2005. Growth,water relations, yield and crop quality of Arabica coffee in response to water stress and deficit irrigation. Ph.D. Dissortion, university putra Malaysia, Maliya.

[28] Tilahun A. and S. Shubert. 2001. Strategic differences in drought resistance between haricot bean (Phaseolus vulgaris L.) andchickpea (Cicer arietinum L.): Stomatal regulation and growth. pp. 91-97. Proceedings of the 10th conference of the Crop Sci. Soci. of Ethiopia 19-21 June 2001. Addis Ababa, Ethiopia.

[29] Yakob, E., K. Taye and Y. Alemseged, 1998. Varietal and age impact on Arabica coffee leaf growth parameters at three locations. Proceedings of the 3rd Conference of Agronomy and Crop Physiology Society of Ethiopia, May 29-30, Addis Ababa, Ethiopia, pp: 38-51.

[30] Zenebe G/Medhin. 2000. The effect of soil water deficit on growth, yield and yield components of cowpea [Vigna unguiculata (L.) Walp.] genotypes. M. Sc. Thesis, Alemaya University.

Citation: Jafer Dawid, “ Effect of Potting Media and Watering Frequency on Growth Rate of Seedling of Korarima (Aframomum Cororima (Braun) P.C.M. Jansen) Under Nursery” International Journal of Research Studies in Agricultural Sciences (IJRSAS), 2020; 6(9), pp. 22-33, https://doi.org/10.20431/2454-6224.0609004

Copyright: (C) 2020 Authors. This is an open-access article distributed under the terms of the Creative Commons Attribution License, which permits unrestricted use, distribution, and reproduction in any medium, provided the original author and source are credited. 